\title{
«Освіта неспокою», активізм і академія: нотатки на полях корисної книжки
}

Kumashiro, Kevin. Troubling Education: Queer Activism and Antioppressive Pedagogy, New York: RoutledgeFalmer, 2002.

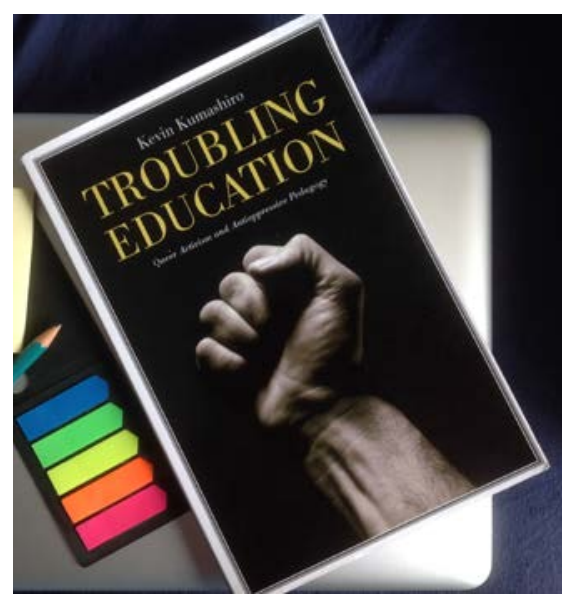
людини». Поміж іншим вона розповіла про свою студентку - активістку, яка багато часу приділяла волонтерству в правозахисній НДО, долучалася до вуличних і медійних акцій, загалом «горіла» справою. На заняттях активістка апелювала до свого практичного досвіду, ставила гострі запитання. Проте моя співрозмовниця була цим радше невдоволеною: вважала, що активізм студентству шкодить - мовляв, потрібно вчитись, опановувати професію. До того ж університет, на її думку, як освітня установа не має нічого спільного з вуличними маршами чи флешмобами в соціальних мережах.

По тому я знову й знову чула схожі висловлювання, тож замислилась: як вибудовуються стосунки між інституціалізованою освітою й активізмом, скерованим на соціальні зміни? Чи є можливими інші візії їхньої взаємодії? У своїх пошуках я натрапила на книжку, що порушувала ті самі питання, - «Освіта неспокою: квір-активізм і антиопресивні педагогіки» ${ }^{1}$ Кевіна Кумаширо. Згодом я пересвідчилися, що цей текст

1 Я передала назву «Troubling Education: Queer Activism and Antioppressive Pedagogy» як «Освіта неспокою: квір-активізм і антиопресивні педагогіки» 3 міркувань не дослівного, а смислового перекладу. Множина «педагогіки» вказує на розуміння терміна як сукупності практик, а не науки, див. докладніше: Плахотник 2013, 362. Варіант перекладу «troubling education» як «освіта неспокою» викристалізувався в обговоренні з Олесею Бондаренко, дякую за той діалог.

(C) Ольга Плахотнік, 2018

(c) Критика феміністична: східноєвропейський журнал феміністичних і квір-студій, 2018, № 1 http://feminist.krytyka.com 
широко вивчають на бакалаврських і магістерських програмах із феміністичних і квір-студій у США й інших країнах, а водночас він $€$ не менш популярним в активістських спільнотах поза академією.

Повна назва книжки чітко вказує на квір-активізм і антиопресивну освіту. Під квір-активізмом автор має на увазі не просто боротьбу за права ЛГБТ ${ }^{+}$, а ширший спектр антинормативних стратегій із залученням феміністичних, антикапіталістичних, антирасистських практик тощо. В Україні квір-активізм уже існує та стрімко розвивається, хоча наразі виглядає на нетиповий і меншинний. Тут книжка Кумаширо стане в пригоді, допоможе квір-активістк_ам рефлексувати їхню діяльність, глибше зрозуміти теоретичне підгрунтя, з якого виростають певні практики, і спрогнозувати відповідний «результат».

Антиопресивні педагогіки - тобто такі, що ставлять за мету виховати соціально чутливих людей, здатних бачити багаторівневі субординації (чи пригнічення, від англ. oppression) у суспільстві й докладати зусиль, аби їх не множити, а навпаки, долати, чинити опір несправедливості, - в Україні теж помалу розвиваються. Щоправда, наразі вони зосереджені передусім на критиці та викоріненні «стереотипів», що теж важить, однак не є винятковим і найдієвішим напрямом роботи. Кумаширо у своїй книжці структурує і теоретично обгрунтовує широкий спектр відомих стратегій - тому ця праця потрібна освітянк_ам, які розвивають антиопресивні педагогіки.

Нарешті, книжка Кумаширо, як на мене, є революційною, адже просуває доволі радикальну ідею про можливість і необхідність нерозривного зв'язку та взаємопроникнення активізму й академії. Ці поняття прийнято мислити відокремлено й ієрархічно: бачимо це зі звичної риторики про «високу» теорію та «низовий» активізм. Однак якщо погуглити англійською «scholar-activist», переконаємося, що критика такої ієрархічності вже лунає на повен голос. Наприклад, Джасбір Пуар, авторка знакової книжки «Терористичні асамбляжі» та концепту гомонаціоналізму, в інтерв’ю 2012 року зазначає:

Ніяк не можу погодитися з бінарністю або чітким розрізненням академічної роботи й активізму. <...> Я не можу сказати, де закінчується мій активістський аналіз і починається моя академічна робота, й навпаки (Greyser 2012).

Академічний активізм (так я переклала scholar-activism) не вичерпується тим, що в часи соціальних заворушень ми виходимо з бібліотек або університетських аудиторій на вулицю та долучаємося до протестних спільнот. Він не зводиться й до лобіювання певних політик за допомоги аргументів і авторитету академії. Як пише Сара Голдрік-Реб, академічний активізм починається з уважної рефлексії над засадничими тезами наших досліджень, триває в прискіпливому критичному аналізі знань, що їх ми продукуємо та викладаємо студентству, й переходить у непрості пошуки способів транслювати результати нашої роботи в соціальні дії. Тут ідеться насамперед про нові й нові відкриті питання, а не про чітко сформульовані цілі; така робота вимагає більше часу, енергії 
та чутливості («тонкої шкіри» за висловом Голдрік-Реб), ніж зазвичай $\epsilon$ достатнім для кар'єри та заробітку (Goldrick-Rab 2014). Гадаю, саме цього різновиду активізму критично потребують українські освітянсько-академічні спільноти, й книжка Кумаширо - про нього теж.

\section{Початкові зауваги}

В головному, теоретичному розділі книжки «Освіта неспокою: квір-активізм і антиопресивні педагогіки» Кумаширо пише про чотири можливі стратегії антиопресивної освіти. Далі я розгляну цю типологію та супроводжу її власними міркуваннями й прикладами. Але спочатку кілька зауваг. По-перше, називаючи описувані підходи, автор звертається до риторики «інших». I хоча сам Кумаширо називає себе квір-активістом, під «іншими» він має на увазі не лише людей ЛГБТ', а поширює поняття на будь-які підпорядковані групи в глобальній системі соціальних ієрархій. Так «іншими» стають жінки (в патріархаті), небілі (в расистській соціальній системі), нижчі класи (в класовому суспільстві), люди без громадянства (в державах) тощо.

По-друге, Кумаширо спирається на критично-педагогічні уявлення про освіту як соціальний інститут, що керується двома протилежними векторами: з одного боку, відтворює наявний соціальний порядок, а 3 другого - створює передумови для критики й трансформації поточної соціальної ситуації. Іншими словами, якщо освітні інституції є місцем розгортання влади різного порядку, як доводить Фуко в «Наглядати й карати» (1998), то освіта - парадоксально - є також місцем можливого та продуктивного спротиву. Темі спротиву владі та логіці «здорового глузду», зрештою, присвячено всі праці Кумаширо: інша його книжка називається, власне, «Проти здорового глузду» (Kumashiro 2009).

Утім, мене непокоїть, що в тексті немає прямої згадки про дискурсивно опресивний характер самого ключового поняття «інші». Й хоча внутрішня філософія праці Кумаширо тяжіє радше до квір- деконструкцій і критики іншування як політично-риторичної фігури, чіткої вказівки на те, що автор послуговується есенціалістським і есенціалізувальним поняттям «інші» свідомо, зі стратегічною метою, мені бракує. Тому я домислюю, що це так.

\section{Підхід перший: освіта для інших² (education for the other)}

Цей напрям міркувань грунтовано на тому, що «інші» $\epsilon$ вони перебувають у підпорядкованому, а отже, в невигідному становищі стосовно привілейованої групи. Тому справедливим буде почасти спрямувати зусилля суспільства саме на «інших» - аби вирівнювати можливості й доступ до ресурсів. У світовій практиці це називають «позитивними ді-

\footnotetext{
${ }^{2}$ Я вживаю множину в перекладі слова Other, тому що це дає змогу знизити андроцентричність україномовного тексту, не спотворюючи оригінальної авторської ідеї.
} 
ями»3: для субординованих груп створюють тимчасові переваги. Найприкметнішими прикладами таких політик $\epsilon$ квоти (визначена конкретна частка представництва для певних соціальних груп) і правила переваги - коли, наприклад, в оголошенні про вакансію зазначають, що за однакового рівня кваліфікованості перевагу буде надано жінкам, або людям з інвалідністю, або людям менш привілейованого етнічного походження тощо.

Теоретичним підгрунтям освіти для інших є уявлення про розмаїття ідентичностей (““інші” є»), які в демократичному суспільстві мусять мати рівні права та можливості. «Різні, але рівні» - широковідоме гасло цього підходу, що визнає та нормалізує розмаїття, однак водночас указує на необхідність забезпечити рівність. Така настанова має не лише визначати індивідуальні поведінкові стратегії викладацтва, а й формувати філософію навчального закладу, його адміністративні політики, курикулум і просторову організацію, форми факультативних подій і активностей.

Освіта для інших означає повне або часткове переспрямування освітніх ресурсів на благо підпорядкованої групи. Передусім ідеться про безпеку - створення комфортного простору для пригнічених груп. Наприклад, моя колега-дослідниця, відвідуючи дитсадок в одній скандинавській країні, зауважила в кутку ігрової кімнати напнутий туристичний намет. 3'ясувалося, що це укриття для дітей, які потребують менше спілкування і зазвичай є стигматизованими серед однолітків, тому потребують відокремленого від групи, комфортного саме для них простору. Як на мене, рішення цілком у дусі освіти для інших. У північноамериканських старших школах (9-12 класи) часто можна побачити веселкові прапорці чи наліпки в кабінетах адміністрації. Вони позначають простори, «дружні до ЛГБТ ${ }^{+} »,-$ такі собі «острівці безпеки» для дітей і юнацтва, субординованих за ознакою сексуальності. Це теж приклад освіти для інших.

До стратегій освіти для інших належить і відокремлене навчання проте саме у формі, спрямованій на «вповноваження», посилення позицій субординованої групи. Наприклад, у Трансильванії діють школи для ромських дітей, створені (часто меценатським коштом і волонтерськими зусиллями) спеціально для того, щоб дати освіту й ширші соціальні можливості маргіналізованій етнічній групі. Ще один приклад: феміністична вповноважувальна політика може передбачати окремі уроки математики, фізики чи комп'ютерних наук для дівчат. Це дає ученицям або студенткам змогу ефективніше й комфортніше опановувати традиційно «чоловічі» царини знання, убезпечитися від хлоп'ячих кпин і хлоп'ячих (культурно обумовлених) переваг у точних і природничих науках. Західні дослідження доводять феміністичну та навчальну продуктивність таких практик.

\footnotetext{
${ }^{3}$ Мені відомі різні назви стратегії надавання переваги; в цьому тексті я вживаю термін «позитивні дії» вслід за підручником «Гендер для медій» (Маєрчик, Плахотнік та Ярманова 2013, 188).
} 
Однак описувана стратегія має слабкі місця. Головне з них, засадниче: освіта для інших конструює, конституює групу «інших», а отже, продовжує відтворювати наявні владні розподіли. Чи можливо подолати несправедливість через хороше, підтримувальне ставлення до «інших», якщо «інші» існують і чітко позначені? Адже існування «інших» - базовий конструкт у підгрунті будь-якого соціального інституту. Цей теоретичний парадокс тягне за собою цілу низку питань і проблем. Як визначити «інших», де провести розділювальну лінію між ними та не-«іншими»? Якщо ми визначаємо групу жінок як «інших» у системі патріархату, куди віднести трансгендерних жінок? Маскулінних жінок? Трансгендерних чоловіків? Інтерсексних людей?

Крім того, фокус на «інших» як окремих індивідах може наводити на думку, ніби пригнічення $є$ наслідком суто індивідуальних упереджень або специфічних взаємодій між окремими людьми (вже згаданих «стереотипів»), що не дає змоги осягнути ширшу картину іншування як форми існування нормативного суспільства та соціальних ієрархій. Ми спостерігаємо результат, проте не надто розуміємо логіку та механіку конструювання й привілеювання «норми», як і маргіналізації «відхилення». Тобто це радше перемикання регістру в психологічно-виховний вимір - замість критично-соціального.

Ще один напрям роздумів про ймовірні слабкі місця освіти для інших стосується тих, хто вчить. Теоретична презумпція цієї стратегії передбачає, що викладацтво й адміністрація навчальних закладів цілком адекватно розуміють потреби та проблеми групи «інших». Та чи завжди це так? Щодо української освіти питання можна переформулювати дещо песимістичніше: хіба так буває? І взагалі, чи можливо однозначно й адекватно знати потреби «інших», а якщо так, чи це не обернеться на колонізаторське «ми краще знаємо, що їм потрібно»?

Кумаширо показує всі ці суперечності й наполягає, що, хоч стратегії освіти для інших потрібні, слід застосовувати їх гнучко й уважно, розуміти механізми іншування, усвідомлювати тимчасовість та інструментальність стратегічного есенціалізму. Потрібно постійно рефлексувати над межами «інших» груп, щоби бачити, де й коли виникають нові субординації й упослідження. Ще одна важлива річ - необхідність комбінувати цей підхід з іншими, про які йдеться далі.

\section{Підхід другий: освіта про інших (education about the other)}

Цей спосіб мислити про антиопресивну освіту, як на мене, $є$ найупізнаванішим у нашій частині світу. Він бере початок у критично-емансипаційній ідеї про те, що в суспільстві домінування одних груп над іншими конституйовано через гегемонію певних форм культури. Наприклад, щодо історії України домінує етноцентрична версія, яка висвітлює буття домінуючого етносу, тому в ній лишаються «невидимими» маргіналізовані етнічні групи - роми, кримські татари тощо. В патріархальному суспільстві й знання, й освіта $€$ андроцентричними, а «жіночі» досвід, 
візії, історії конструйовано як другорядні чи взагалі виключено з гегемонного знання. Відповідно, підважувати несправедливий статус-кво потрібно через включення знань про «інших» у канон.

Цей підхід зіперто на ідеї, що упередження стосовно «інших» $\epsilon$ наслідком нестачі знань, тому «включення», «додавання» - засадничі поняття цього способу освіти. Тут зазвичай ідеться про необхідність змінювати зміст освіти: доповнювати вже наявні навчальні програми вичерпними та правдивими даними про маргіналізовані групи. Це стосується й власне курикулуму, й менш очевидних пластів знання й організації освіти. Феміністична освіта про інших передбачає першим кроком «ґендерну експертизу», або «гендерний аудит» (я впевнена, обидва формулювання $\epsilon$ вже узвичаєними та зрозумілими в українському освітянському середовищі) підручників, навчальних програм, шкільного чи університетського простору. А потім потрібно «додавати жінок» туди, де їх несправедливо мало: в історію та суспільствознавство, в літературу та мистецтво, в описи розвитку наук, в ілюстративні матеріали підручників, на плакати й настінні портрети, в сценарії святкувань тощо. Ще одним важливим завданням цього підходу є розвінчування хибних знань про «інших», тобто стереотипів. Позаяк стереотипізація спотворює картину світу на користь одних і на шкоду іншим, слід показати непродуктивність (і політичність) стереотипів, закликати учнівство й освітян бачити їх і уникати. Таку риторику теж широко застосовувано в Україні в багатьох царинах, зокрема в освітній.

Позитивні соціальні наслідки освіти про інших є доволі очевидними навіть для нефахової аудиторії - й це, до речі, одне з пояснень її популярності в більшості країн світу. По-перше, в цілком просвітницьких традиціях цей підхід спрямовано на просування нових знань у маси. $€$ навіть термін «ґендерна просвіта». При цьому освіту про інших, на відміну від попередньої стратегії, скеровано на всіх людей нарівно: так вона, згідно із задумом, сприяє суспільній емпатії та співпереживанню людям із пригнічених соціальних груп, формує відчуття власної гідності й прагнення справедливості в групі «інших».

Однак слід зважати на методологічну специфіку такої роботи, що розв'язує низку проблем, але водночас відкриває нові й нові питання. Теоретична презумпція освіти про інших, як і в попередньому підході, полягає в тому, що ми завжди напевно знаємо, хто такі «інші»: іншість $\epsilon$ чітко визначеною, есенціалізованою, протиставленою так само чітко визначеній «нормі». Тобто ми знову опиняємося в бінарній системі «норма - відхилення», де кожен полюс конституює свою протилежність. Освіта про інших не може сприяти тому, щоб «інші» перестали бути «іншими»: як і освіта для інших, вона конструює та закріплює іншування.

У цьому підході $\epsilon$ ще одне проблемне місце: «іншим» надано експертний статус щодо їхнього становища, бо вони мають безпосередній досвід пригніченості. Наприклад, ніхто не знає краще за жінок, що таке бути субординованими за статевою ознакою. В цій конструкції геї та лесбійки мають експертне знання з проблеми гомофобії, небілі люди краще за білих розуміють расизм тощо. До такого експертного статусу 
часто апелюють у лібертарних освітніх практиках. Наприклад, в Україні дедалі популярнішим різновидом неформальної освіти стають так звані «живі бібліотеки», де роль окремих «книжок» часто грають люди з маргіналізованих соціальних груп, які діляться власним досвідом, і це знання дискурсивно сприймано як «істинне», «експертне».

Звісно, розказаний прожитий досвід вартий уваги та має безперечну політичну вагу. Однак вважаю помилковим апелювати до досвіду певної соціальної групи як остаточного знання, вже готового підгрунтя для соціальних політик. Артикуляція потреб і проблем ніколи не відображає «чистого досвіду», а є радше відбитком дискурсів, уже наявних риторичних фігур. Наприклад, викладаючи феміністичні курси, я регулярно чую від українських студенток репліки про те, що ні вони самі, ні їхні подруги, мами чи бабусі ніколи не потерпали від сексизму, утисків і пригнічення за ознакою статі. Мовляв, навпаки, на рівні досвіду буття жінками вони почуваються радше привілейованими, ніж субординованими. Чи маю я сприймати це знання як «істинне»? Я переконана, що досвід конструюється в контексті - в межах риторичних стратегій, що вже існують і домінують у дискурсі. Про це писала Джоан Скотт:

\begin{abstract}
Коли ми беремо досвід як джерело знання, то точка зору індивідуального суб'єкта (людини - носійки досвіду чи історикині_, що вивчає досвід) стають основою для побудови пояснень. Питання про конструйованість досвіду, про те, чому суб'єкти конституюються передусім різними, або як чиїсь уявлення обумовлює мова чи дискурс, - усі лишаються осторонь. Очевидність досвіду в такому разі радше доводить існування відмінності, а не стає способом дослідження того, як саме встановлювано відмінність, як вона оперує, як конституює суб'єктів, що бачать і діють у світі (Scott 1991, 777).
\end{abstract}

3 одного боку, почути голоси людей із маргінальних, субординованих груп важливо. Цю стратегію часто беруть на озброєння різного штибу правозахисні організації чи академічні дослідни_ці «усної історії», й вона справді може ефективно змінювати масову свідомість і пом'якшувати соціальну стигму. Але водночас такий підхід укріплює есенціалістське розуміння ідентичності як сталої («вона $\epsilon$ ромкою», «вона $\epsilon$ лесбійкою»), а досвіду - як прямого, нічим не опосередкованого, правдивого знання. Так есенціалізуються соціальні відмінності, посилюється й переукріплюється протиставлення «норми» й «інших».

\title{
Підхід третій: \\ освіта, що критикує привілеї та іншування (education that is critical of privileging and othering)
}

Кумаширо пропонує подивитися на антиопресивну освіту з іще однієї перспективи. Що як поставити за мету формувати в студентства критичний погляд на субординування та привілеювання в освіті (й у суспільстві загалом)? Бачити, як соціальні інститути й гегемонні дискурси конструюють і відтворюють нерівності? Навіть більше - розуміти реальні можливості для спротиву та боротьби з несправедливістю, тобто 
не лише «знати, як це працює», а й «знати і діяти»? Кумаширо називає цей підхід освітою, що критикує привілеювання й іншування (education that is critical of privileging and othering), а я задля лаконізму вживатиму коротше формулювання «проблематизаційна освіта».

Така освіта пропонує аналітичну оптику, щоби бачити не лише наявний стан речей, а й нюанси внутрішніх механізмів складного соціального світу: розуміти, як саме вибудовуються норми та відхилення, привілеї та пригнічення, а отже, бачити можливості альтернативних конструкцій. Важливим $\epsilon$, наполягає Кумаширо, не так теоретично засвоїти аналітичне критичне мислення, як формувати навички для аналізу власного життєвого досвіду за допомоги отриманого критичного інструментарію та водночас бачити в особистому досвіді відображення глобальної соціальної системи.

У цьому ракурсі вперше проявляється «активізм»- не як додатковий щодо освіти вид діяльності, а як засадничий концепт, смислотворчий складник мети: навіщо ми вчимо(ся)? Наголошення на діях, на соціальній практиці надихає: освіта конституює активізм, вона і $€$ активізм, вони в єдності прагнуть зробити світ кращим, справедливішим.

Важливо, що цей підхід охоплює все студентство, нікого не вирізняючи. Це дає змогу, поміж іншим, продуктивно розв'язувати питання альянсів, тобто співпраці людей із субординованих і привілейованих груп задля спільної мети. В річищі цієї стратегії чоловіки стають феміністами, гетеросексуальні та цис-люди долучаються до боротьби за права ЛГБТ ${ }^{+}$, а білі - до протистояння расизмові. Звісно, на ділі це непросто, адже привілейовані групи мусять постійно додатково працювати над своїми привілеями. Проте саме підхід проблематизації, на відміну від попередніх, бодай теоретично уможливлює альянси. Це неабиякий плюс.

Слабкі місця цього підходу почасти такі самі, як і в попередніх стратегіях: «інші» тут $є$ чітко визначеними та виглядають на гомогенну групу зі схожим досвідом пригнічення. А нова потенційна проблема лежить у полі уявлень про студентство як соціально активну групу, готову боротися з несправедливістю, - адже це не завжди так. Західні публікації з антиопресивних педагогік описують дуже різні досвіди: наприклад, подеколи проблематизаційна освіта викликала в студентства з домінуючих груп почуття провини й навіть депресії замість натхнення до активізму. Ще одне непевне місце: підхід проблематизації виходить із презумпції, буцім викладацтво свідомо планує та досягає мети навчання через адекватні теми й методи. А що як реальні результати викладання насправді не $є$ передбачуваними?

Наведу приклад від мого колеги з Університету Південної Флориди (США). Черговий «ґендерний» курс мав несподівані наслідки, коли студентство, щойно озброєне аналітичною оптикою проблематизації, зауважило логічну суперечність між двома світоглядними позиціями викладача: між ідеологічним вегетаріанством як визнанням прав тварин і «прочойс»-позицією стосовно репродуктивних прав жінок. Суперечність полягала в тому, що засаднича для першої позиції ідея «захисту права на 
життя» мала б логічно продовжуватися в ідеології «пролайф», аж ніяк не «прочойс». Колега-викладач дуже тішився цим випадком як переконливим доказом успішності курсу: студентство справді засвоїло критично-проблематизаційний метод і застосовує його самостійно. Проте ситуація, коли студентська аудиторія скеровує вістря проблематизаційної критики на тих, хто їх цим методом озброїли, може бути неочікуваною. Такі «незручні моменти» стають серйозним педагогічним викликом і потребують методологічно й емоційно непростої роботи викладацтва над власними структурними привілеями в освітньому просторі.

Непередбачуваність результатів проблематизаційної освіти може розгортатися в ще одній площині - коли студентство набуває почуття загроженості й відмовляється засвоювати критично-проблематизаційний спосіб мислення. Такий протест може бути узагальненим: мовляв, «не примушуйте нас думати, а скажіть, яка відповідь правильна». Яскравий приклад такого спротиву продемонстровано в художньому фільмі «Усмішка Мони Лізи», де студентки-відмінниці відчувають загрозу своєму високому статусу через новий - проблематизаційний - викладацький підхід. Імовірність студентського опору дедалі зростає, коли навчання зачіпає соціально й особисто значущі теми, бо тоді з'являється можливість звинуватити викладацтво в ідеологічній упередженості, «однобокості», пропаганді. Я чула немало таких історій із різних країн, аж до геть анекдотичної, коли студентство українського вишу скаржилося в деканат на буцімто «пропаганду орального сексу» під час занять. А йшлося про стадії психосексуального розвитку за теорією Фройда - в рамках курсу з психології.

Якщо говорити серйозно, студентський опір нерідко виникає під час обговорень сексуальності, раси, фемінізму та прав жінок, міграцій, релігій і багатьох інших тем, які оприявнюють і ставлять під питання «невидимі» привілеї чи здоровоглузді переконання студентства. На своїх заняттях я час од часу чую некритично повторюване банальне твердження, мовляв, «насправді найпривілейованішими людьми у світі $\epsilon$ небілі матері-одиначки-лесбійки з інвалідністю, а от білі гетеросексуальні чоловіки-християни нині $\epsilon$ найбільш дискримінованою соціальною групою». Що це, коли не слабо усвідомлюване намагання відстояти власні загрожені привілеї?

Коли йдеться про антиопресивну освіту, важливо пам'ятати, що описані вище стратегії можуть переплітатися та збігатися. Пригадуєте, в першій частині я згадувала про веселкові прапорці чи наліпки в школах? У контексті «безпечного простору» для людей зі стигматизованих груп це було ілюстрацією освіти для інших. Однак ці прапорці можуть відігравати чималу роль в освіті про інших, адже, позначаючи певні соціальні групи, вони роблять їх видимими, спонукають про них думати. Крім того, веселкові прапорці зі своїм символічним навантаженням можуть мати справді підривний ефект щодо переконань, ніби «сексуальності не місце в школі» або «це пропаганда». Безсловесні прапорці можуть стати місцем неспокою, викликати протест або, в продуктивнішому випадку, запустити критичне переосмислення наявного здорово- 
глуздого знання. Зрештою, й самі ці прапорці - як позначники окремих «типів людей» - теж можна поставити під питання - в парадигмі четвертого підходу до антиопресивної освіти.

\section{Підхід четвертий: освіта, що змінює студентство та суспільство (education that changes students and society)}

Існує модель антиопресивної освіти, яка відмовляється визнати стабільність ідентичностей, тобто бачити домінуючі й «інші» групи сталими та чітко визначеними. Цей підхід епістемологічно угрунтовано в постмодерному, постструктуралістському погляді на ідентичності як завжди плинні й рухомі, на знання як завжди необ'єктивні та ситуйовані, на пригнічення як на дискурсивний конструкт «нескінченного повторення та доповнення» (Джудіт Батлер) на різних рівнях, від індивідуального до інституційного. Пригнічення з цієї перспективи теж постає не прямим і механістичним, а дискурсивно конструйованим і динамічним. Відповідно, для спротиву владі замало критичного бачення та заборони пригнічувати: потрібно створювати нові, альтернативні дискурсивні конструкти. Нині цей спосіб думання розробляє квір-теорія.

Кумаширо називає четвертий підхід «освітою, що змінює студентство та суспільство» (education that changes students and society), а я для зручності вживатиму формулювання «трансформативна освіта». В цій моделі суттєво переосмислено «слабкі місця» попередніх трьох стратегій. По-перше, тут немає чітко визначених «інших», а процеси іншування критично препаровано як такі, що натуралізують уже встановлені нерівності. Це засаднича ідея квір-теорії. Тож сам дискурс критичної теорії (та критичної педагогіки) можливо поставити під сумнів і деконструювати як такий, що стартує з підривної, революційної позиції, але згодом у певних контекстах перетворюється на гегемонний владний дискурс, що може витісняти інші форми знання. Тобто трансформативна освіта порівняно з попередніми підходами $\epsilon$ ще чутливішою та (само)критичнішою до владних дискурсів, і це становить її перше та постійне завдання.

По-друге, трансформативна освіта, на відміну від попередніх трьох стратегій, пропонує людині аналітичний інструментарій для переосмислення власних привілеїв. Це важливий етап квір-мислення, хоча на ділі подеколи вкрай непростий. Пригадую свого студента, який мало не плакав від нездатності помислити свої чоловічі привілеї: «Але я не почуваюся привілейованим! Як це сумістити з тим, що насправді моє життя дуже скрутне, я заледве виживаю?» Усвідомлення власних привілеїв часто передбачає кризовий етап, і тут зупинюся для докладнішого аналізу, оскільки поняття кризи є важливим у квір-теоретичному осмисленні освіти й водночас доволі новим на наших освітніх теренах.

Передусім, коли ми так чи так починаємо розмову на соціально чутливі теми, це знання ніколи не є для студентства цілковито новим, призначеним лягти в буцімто «порожню», нічим іще не заповнену комірку 
в мозку. Навпаки, ми змалку засвоюємо побутові іншувальні уявлення про «девіантні групи» в межах масової свідомості й здорового глузду. Тому, щоб викрити системні пригнічення, спонукати студентство не миритися з несправедливістю й боротися за кращий світ, не досить просто «збільшувати знання» про соціальне життя. Потрібне спеціальне «підривне знання» (disruptive knowledge), вважає Кумаширо. Це парадоксально означає:

...nіддавати знання та спосіб їх формування критичній перевірці, бачити їхні обмежувальні наслідки та водночас утримувати в полі зору, які інсайти, ідентичності, практики та зміни уможливлювано цими-таки знаннями (Kuтаshiro 2009, 127).

Ідея «підривного знання» $є$ дуже постмодерною, адже, на відміну від просвітницьких уявлень про накопичення знань як безумовне благо, диференціює освітні ситуації й отриману інформацію залежно від того, що відбувається з уже наявною особистою «картиною світу» людини. Елізабет П'єрр, теоретикиня постмодерної освіти, описує «підривне знання» як «аналітичний погляд на будь-яку здоровоглузду ситуацію, будь-які звичні події чи процеси, аби думати про них по-іншому - поставити під сумнів і побачити інші можливості в нібито "природному" та “нормальному"» (Pierre 2000, 479).

Курси $з$ гендерних студій, квір-теорії, критичних досліджень сексуальності, раси, націоналізму тощо, вибудувані з критичної конструкціоністської перспективи, стають найсприятливішим середовищем для «підривного знання». Студентство приходить з уже сформованим (здоровоглуздим, буденним, безпроблемним) уявленням про предмет курсу, а тоді в класі розгортається «освіта неспокою», що перериває цю безпроблемність, бо вчить ставити під питання речі, які доти питань не викликали (Kumashiro 2009). I «неспокій» тут $\epsilon$ не лише метафорою специфіки знань, а й влучним означенням імовірних емоційних переживань аудиторії. Уявіть: ви приходите вчитися й помалу переконуєтеся, що ваші дотеперішні знання не просто хибні чи неточні, а й є складником режимів нерівностей, тобто політично підтримують пригнічення певних соціальних груп. Ваше уявлення про себе та світ втрачає сталість і надійність, а це - зазвичай стресове переживання. І я, й мої колеги неодноразово мали нагоду пересвідчитися в цьому по обидва боки викладацької кафедри. Ось, наприклад, цитати з анонімних студентських відгуків на завершення курсу в одному українському виші:

«На першій лекції ви сказали: студенти говорять, що не можуть спокійно спати після цього курсу. Тепер я їх розумію :)»

«Курс виявився для мене більш кризовий, ніж я очікувала (знайшлися місия в свідомості, які варто відрефлексувати та позбутися)...»

Один із моїх студентів безпосередньо під час заняття з гендерних студій описав свій емоційний стан так: «Я почуваюся повішеником, 3-під чиїх ніг просто зараз вибивають стілець». Так гостро він зреагував на критичну деконструкцію гендерно поляризованої моделі нуклеарної «традиційної сім'ї» (чоловік заробляє - дружина виховує дітей і веде 
хатнє господарство). Тобто, підсумую: кризи трапляються, й це радше бажаний, аніж зайвий етап студентського «проживання» зустрічі з підривним знанням.

На думку Кумаширо, в основі емоційних реакцій, що призводять до кризи в студентській авдиторії, лежить спротив. Освіта, що змінює студентство та суспільство, $\epsilon$ неможливою без спротиву змінам - з боку суспільства й студентства (Kumashiro 2002, 62). Студентство може опиратися «підривним знанням», оскільки вони вимагають не лише навчитися нового, а насамперед звільнитися від старих знань, що разом утворює «парадоксальну ситуацію навчання та розучування [learning and unlearning]» (Kumashiro 1999).

Розучування - ще одне важливе поняття постмодерної антиопресивної освіти. Обгрунтовуючи його, Кумаширо посилається на праці Дебори Бріцман, зокрема на поняття «бажання не знати» [a passion for ignorance], коли запропоноване знання викликає в студентства не волю до навчання, а бажання не знати (Britzman 1998, 57). Останнє виникає переважно, коли ми - студентство й викладацтво - стикаємося зі знанням, що підриває усталені уявлення про нормальне та нормативне, вимагає їх «демонтувати» (розучитися). Тут Бріцман пропонує квір-підхід ${ }^{4}$, що дає змогу усвідомлювати, відкривати, називати «непроговорювані чинники», які витісняють певні знання чи певні способи мислення поза освітню ситуацію. Заохочуючи нас до такого самоаналізу, «квір-теорія пропонує освіті спеціальні техніки, аби зауважити й побачити сенс у тому, що зникає з поля нашої уваги та не може бути вивченим» (Britzman 1998, 214).

Квір-педагогіка (або, за Кумаширо, четвертий тип антиопресивної освіти), подібно до інших радикальних педагогік, вибиває з рівноваги, бентежить, конфузить; часом вкидає в стресовий стан нерозуміння, відчуття неспроможності зрозуміти. Проте саме такий стан, у традиційній освіті відчитуваний як неуспіх, у квір-перспективі може стати передумовою глибоких інтелектуальних відкриттів. Навіть коли нам бракує відповідей, однак ми переповнені запитаннями, різночитаннями та різними трактуваннями, - це важливі передумови нових можливостей.

\section{Замість висновків, або Що не так із толерантністю?}

Кумаширо підсумовує свою класифікацію антиопресивних педагогік закликом до освітян «застосовувати сплав усіх чотирьох моделей» $\mathrm{i}$ закликом «досліджувати більше невизнаних або недовивчених спосо-

\footnotetext{
${ }^{4}$ Квір-педагогіка, або квір-підхід до викладання - це переосмислення освіти й експерименти в практичному викладанні, угрунтовані в квір-теоретичній критиці ідентичності й нормативності, зосереджені навколо тематики статі, гендеру та сексуальності, а також такі, що аналізують нормативності в ширшій (інтерсекційній) перспективі. Див., наприклад, Pinar 1998, або мої публікації (Плахотник 2013; 2014).
} 
бів антиопресивної освіти» (Kumashiro 2002, 70). Тому я хочу завершити аналіз різних стратегій антиопресивних педагогік розділом уже не про книжку як таку, а про конкретний антиопресивний освітній проект, що сформувався під прямим впливом розвідок Кумаширо. Йдеться про норм-критичні [norm-critical] педагогіки.

Я вже зазначала, що з-поміж описаних Кумаширо чотирьох підходів два перші - освіта для інших і освіта про інших - $є$ найпоширенішими в Україні та світі. Вони мають тривалішу історію та є доступнішими для розуміння; водночас вони не проблематизують власної позиції тих, хто вчать і хто вчаться. Мовляв, «інші» таки існують, потрібно лише поліпшити суспільне ставлення до них. При цьому, однак, привілеї самих викладацтва та студентства не тільки залишаються невидимими, а й, навпаки, посилюються через владну позицію «толерування» іншості. Адже толерувати можуть лише ті, хто посідають владу: владна позиція вибудовується зокрема й через можливість когось «толерувати». Сам концепт толерантності, дуже поширений у сучасному правозахисному й освітньому дискурсах, виглядає на такий, що конституює владу та нормативні розподіли.

Кумаширо у своїй книжці не розгортає критики концепту «толерантності» як дискурсивно нормативного й опресивного. Проте я вважаю цей момент вагомим, тому бодай коротко опишу освітню модель, яка експліцитно таку критику артикулює, - норм-критичну педагогіку. Публікації з норм-критичної педагогіки надаються до пошуку за іменами авторок: Лєна Мартінссон, Єва Реймерс, Єн Бромсет, Реніта Сьоренсдоттер та інші (Bromseth and Darj 2010; Bromseth and Sörensdotter 2013; Martinsson and Reimers 2010). Багато хто проводить паралелі між трансформативною освітою за Кумаширо та норм-критичною педагогікою, які виростають з однієї теоретичної рамки (ім'я їй - квір-теорія). Кумаширо теж визнав цей зв'язок і написав післямову до однієї з перших публікацій із норм-критичної освіти - антології «Норм-критична педагогіка - влада в навчанні та стратегії змін» («Normkritisk pedagogik - makt lärande och strategier för förändring»).

Авторки норм-критичної педагогіки спираються на думку, що ідеологічною «візитною карткою» сучасної Швеції $€$ так звана «гомотолерантність» (термін Оси Росінг). Толерантність до гомосексуальності формується багатьма засобами, зокрема й законодавчими реформами впродовж попередніх трьох десятиліть, що обумовили захищеність і видимість ЛГБТ ${ }^{+}$у Скандинавії, зробили їхні життя безпечнішими та комфортнішими. Але це ніяк не похитнуло інституту «обов'язкової гетеросексуальності» (Едріен Річ); навпаки, дискурс гомотолерантності додатково укріплює привілейований статус гетеросексуальної норми. До того ж «гомотолерантність» $є$ вагомим складником конструювання моральної вищості шведського суспільства над «типово гомофобними» мігрантськими спільнотами - тобто задіяна у створенні расистських, антимігрантських іншувань і виключень.

Норм-критична педагогіка з'явилась у Швеції в середині 2010-х років у результаті кількарічної співпраці групи людей з активістського та (чи водночас із) академічного середовищ. Вихідною точкою була ідея 
виробити стратегію подолання гетеронормативності в освіті, але дуже скоро вона набула універсальнішого, інтерсекційного виміру - піддавати постструктуралістській критиці не лише гендерні норми щодо сексуальності, а й усяку нормативність: расову, класову, вікову, пов'язану з тілесністю тощо. В теоретичне підгрунтя норм-критичної педагогіки покладено критику норм і нормативностей, що бере початок у працях Мішеля Фуко, а згодом її розвивають Джудіт Батлер, Розі Брайдотті, Шанталь Муф і Ернесто Лакло, Герт Бієста й інші (Martinsson and Reimers 2010). Позаяк місія освітніх інституцій полягає в продукуванні «правильних громадян_ок» для національної держави, то школа є тим місцем, де норми, накладені на студентство й викладацтво, постійно відтворюються, стають «природними» та безпроблемними - мовляв, «а як іще?». Наприклад, Ліна Майя Россі називає школу «гетерофабрикою» - тобто соціальним інститутом, що послідовно й ефективно формує суб'єктів через гегемонну норму гетеросексуальності (Rossi 2010). Водночас сама тематика сексуальностей залишається невидимою, бо перебуває поза курикулумом і формально артикульованими виховними завданнями навчальних закладів.

Норм-критичний підхід дає змогу побачити соціальну конструйованість норм, а отже, відкриває можливість «деконструювати» їх - висувати до них питання, сумніватися в їхній однозначності, в самоочевидності здоровоглуздих висновків. Підважувати гегемонні норми та нормативності в школі означає критично розглядати не лише гетеронормативність, а й будь-які звичні розмежування та розподіли: між тими, хто вчить, і тими, хто вчиться, між дорослими та дітьми, між статями, расами, етнічними групами, нормами функціональних можливостей і форм тілесності тощо. А це, своєю чергою, звільняє простір для спротиву, для вироблення нових норм поза гегемонними порядками - й урешті-решт для суспільних змін.

Норм-критичний, або ж квір-погляд, зрештою, здатен підважити ще одну норму: домінуючий статус спеціальних інституцій у продукуванні й трансляції знань. Так дістаємо змогу мислити «антиопресивну освіту» як розмаїття педагогічних практик, що їх можна реалізовувати поза освітніми закладами: на майданчиках «вільних» або «вуличних» університетів, активістських тренінгів і акцій, навіть під час дружніх посиденьок за кавою. Справді важливе навчання - трансформативна освіта зокрема - може відбуватися будь-де. Звикаймо до думки, що монополію академії на знання й освіту теж потрібно підважити і зруйнувати. Тоді, можливо, наші університети ставатимуть гнучкішими, відкритішими та відповідальнішими, а наше суспільство - справедливішим до всіх:

Водночас я визнаю, що така робота часто потребує субверсивного погляду на цілі освіти, ролі й обов'язки викладацтва, на те, як ми хочемо змінити студентство та суспільство. Також я розумію, що навіть із таким субверсивним поглядом змінити нашу освітню систему в сучасному політичному кліматі є надто складним завданням. Однак я вірю й показую... як дедалі більше освітян наважуються стати на шлях антиопресивної освіти, в такий спосіб спричиняючи реальні зміни в житті студентства (Kuтаshiro 2002, 70-71). 


\section{Подяки}

Дякую Програмі імені Фулбрайта та програмі «Visby» Шведського інституту за підтримку моїх досліджень радикальних педагогік у США та Швеції, а також колективам кафедр гендерних студій Університету Південної Флориди та Університету Лінчопінга. Я глибоко вдячна Марії Маєрчик за уважне прочитання та слушні коментарі до попередньої версії цього тексту.

Маєрчик, Марія, Ольга Плахотнік, Галина Ярманова, ред. 2013. Гендер для медій. Підручник із гендерної теорії для журналістики та інших соціогуманітарних спеціальностей. Київ: Критика.

Плахотник, Ольга. 2013. «Квир-педагогики и постсоветское образование: где выход из эпистемологического и политического тупика?» Ha перепутье: методология, теория и практика ЛГБт и квир-исследований: Материалы международной научно-практической конференции, 359-78. Санкт-Петербург: ЦНСИ.

Плахотнік, Ольга. 2014. «Радикальні педагогіки в контексті “студентоцентрованої" соціогуманітарної освіти». Соціологія: теорія, методи, маркетинг, № 4: 171-86.

Фуко, Мішель. 1998. Наглядати й карати: Народження в'язниці, пер з фр. Петро Таращук. Київ: Основи.

Britzman, Deborah. 1998. Lost Subjects, Contested Objects: Toward a Psychoanalytic Inquiry of Learning. Albany: State University of New York Press.

Bromseth, Janne, and Frida Darj, eds. 2010. Normkritisk Pedagogik : Makt, Lärande Och Strategier För Förändring. Uppsala: Uppsala universitet.

Bromseth, Janne, and Renita Sörensdotter. 2013. "Norm-Critical Pedagogy." In Gender Studies Education and Pedagogy, 24-32. Gothenburg: Swedish Secretariat for Gender Research.

Goldrick-Rab, Sara. 2014. "On Scholarly Activism - Contexts." Contexts Blog. http://contexts.org/blog/on-scholarly-activism.

Greyser, Naomi. 2012. "Academic and Activist Assemblages: An Interview with Jasbir Puar." American Quarterly 64 (4): 841-43.

Kumashiro, Kevin. 1999. 'Barbie,' 'big Dicks,' and 'faggots': Paradox, Performativity, and Anti-Oppressive Pedagogy." Journal of Curriculum Theorizing 15 (1): 27-42.

Kumashiro, Kevin. 2002. Troubling Education: Queer Activism and Antioppressive Pedagogy. New York: Routledgefalmer.

Kumashiro, Kevin. 2009. Against Common Sense: Teaching and Learning Toward Social Justice, Revised Edition. Revised edition. New York ; London: Routledge.

Martinsson, Lena, and Eva Reimers, eds. 2010. Norm-Struggles: Sexualities in Contentions. Cambridge Scholars Publishing.

Pierre, Elizabeth Adams St. 2000. "Poststructural Feminism in Education: An Overview." International Journal of Qualitative Studies in Education 13 (5): 477-515.

Pinar, William, ed. 1998. Queer Theory in Education. Psychology Press.

Rossi, Leena-Majia. 2010. "How to Make (Visual) Trouble Inside Hetero Factory?" In Norm-Struggles: Sexualities in Contentions, 83-97. Cambridge Scholars Publishing.

Scott, Joan W. 1991. “The Evidence of Experience.” Critical Inquiry 17 (4): 773-97. 